\title{
MATING DISRUPTION WITH LOW DENSITY DIFFUSERS FOR THE MANAGEMENT OF ORIENTAL FRUIT MOTHS (LEPIDOPTERA: TORTRICIDAE) IN APPLE ORCHARDS UNDER SUBTROPICAL CLIMATE IN SOUTHERN BRAZIL ${ }^{1}$
}

\author{
LINO BITTENCOURT MONTEIRO², ALEXANDER SOUZA ${ }^{3}$, JEFERSON ARGENTON $^{4}$
}

\begin{abstract}
The oriental fruit moth, Grapholita molesta Busck, and fruit flies, Anastrepha fraterculus L., are the important apple pests under Subtropical climate in Southern Brazil, and control is normally accomplished with insecticides. An alternative strategy for the control of G. molesta is mating disruption, through the use of pheromones. Mating disruption strategies using a low density of dispensers (20) per hectare were tested in comparison with conventional pesticides for control of G. molesta in commercial Gala apple orchards in Fraiburgo, SC, for a period of five years. The average field efficiency period of mating disruption formulation over five years was 113 days. In this period the mating interruption index on mating disruption plots was $84.8 \%$ over five years. Damage to Gala apples by oriental moth larvae was low $(<0.1 \%)$ in mating disruption plots but did not differ from conventional plots, except in the third year. The use of mating disruption allowed for an average reduction of 5.2 insecticide treatments per year in Gala orchards during field efficiency period. It was necessary to apply 1.0 and 1.2 applications of insecticide to control of G. molesta and A. fraterculus, respectively. Mating disruption with a low density of diffusers proved to be an effective alternative to conventional methods for control of G. molesta in Gala apple orchards in subtropical climate in southern Brazil.
\end{abstract}

Index terms: oriental fruit moth; pheromone; apple orchard; pest management.

\section{CONFUSÃO SEXUAL COM BAIXA DENSIDADE DE DIFUSORES PARA O MANEJO DA MARIPOSA-ORIENTAL (LEPIDOPTERA; TORTRICIDAE) EM POMARES DE MACIEIRA EM CLIMA SUBTROPICAL NO SUL DO BRASIL}

RESUMO - Mariposa-oriental, Grapholita molesta Busk, e moscas-das-frutas, Anastrepha fraterculus L., são importantes pragas de macieira em clima Subtropical no sul do Brasil e o controle é normalmente realizado com inseticidas. Uma estratégia alternativa para o controle de G. molesta é confusão sexual, por meio de feromônios. Estratégias de confusão sexual, usando uma baixa densidade de dispersores (20) por hectare, foram testados em comparação com pesticidas convencionais para o controle de G. molesta em pomares comerciais de maçã Gala em Fraiburgo, SC, por um período de cinco anos. O período médio de eficiência em campo da formulação na interrupção de acasalamento, durante cinco anos, foi de 113 dias. Neste período, o índice de interrupção de acasalamento em parcelas de confusão sexual foi de 84,8 \%. Danos à Gala por larvas de mariposa-oriental foi baixa $(<0,1 \%)$ em parcelas de confusão sexual, mas não diferiram das parcelas convencionais, exceto no terceiro ano. O uso da formulação de confusão sexual permitiu uma redução média de 5,2 tratamentos com inseticidas por ano em pomares de Gala durante o período de eficiência em campo. Foi necessário aplicar 1,0 e 1,2 aplicações de inseticidas para o controle de G. molesta e $A$. fraterculus, respectivamente. Confusão sexual com uma baixa densidade de difusores provou ser uma alternativa eficaz aos métodos convencionais para o controle de G. molesta em pomares de maçã Gala em clima Subtropical no sul do Brasil .

Termo para indexação: Grapholita molesta, feromônio, macieira, manejo de pragas.

\footnotetext{
'(Trabalho 209-13). Recebido em: 20-05-2013. Aceito para publicação em: 01-11-2013.

${ }^{2}$ Professor of Federal University of Paraná, Departament of Crop Protection, Curitiba, PR, Brazil.Correspondence to: Federal University of Paraná, 1540 Funcionários Stret,80035-050, Curitiba, Brazil. E-mail: lbmonteiro@terra.com.br

${ }^{3}$ Agronomist of Agrícola Fraiburgo Ltda, Sc Rodovia SC 453, km453, 89580-000, Fraiburgo-SC, Brazil. E-mail engalexsouza@ hotmail.com

${ }^{4}$ Agronomist of Fischer S/A Agroindústria, Caixa Postal 131, 89580-000, Fraiburgo-SC, Brazil. E-mail jargenton@fischerfrutas.com
} 


\section{INTRODUCTION}

Oriental fruit moth, Grapholita molesta (Busck) (Lepidoptera: Tortricidae) is a major pest of stone and pome fruits in Southern Brazil (HICKEL et al. 2003a), since the first occurrence as economic pest on apple was in the 1988 (LORENZATO 1988). In subtropical conditions, the emergence of adults from larvae in diapause is irregular in time (HICKEL et al. 2003b), preventing the definition of Biofix, as occurs for Cydia pomonella L. (Lepidoptera: Tortricidae) (PITCAIRN et al. 1992). The biofix is the date from which it obtains consistent catches of moths in pheromone traps (RIEDL et al. 1976, RICE et al. 1984), the basis for predicting the flight of Oriental fruit moth. In the absence of these data, the trend is to apply preventive sprays to G. molesta until the end of the summer generation (STRAND 1999; HICKEL et al. 2003a). Simultaneously, there is the occurrence and damage by South America fruit flies, Anastrepha fraterculus (Diptera: Tephritidae) (KOVALESKI et al. 1999).

Control of tortricids moths and fruit flies were normally carried out using several organophosphate and pyrethroid insecticides, the first spraying occur at pre-flowering and flowering. The total is more than 12 insecticide sprays per season. The frequent use of insecticides in apple orchards may result in the selection of resistant populations, as evidenced by the inefficient control of Lepidoptera that has been frequently observed in Southern Brazil (SIEGWART et al. 2011) and other locales (KANGA et al. 2001). Some active substances, such as clorpyrifos, phosmet, fenitrothion and methidathion have not shown promising results with regard to the efficiency of pest control which targets using chemical insecticides (L.B.M., unpublished data).

An alternative to conventional control programs is the use of mating disruption (CARDÉ AND MINKS 1995). In this technique, pheromones are released into the atmosphere to interfere with sexual communication between male and female moths (KOVANCI et al. 2005). Mating disruption is used in many countries to control of Lepidoptera, which damage fruit trees in temperate climates (JENKINS, 2002). Initially, Mating disruption protocols for Oriental fruit moth were tested with 500 to 1000 dispensers per hectare (ROTHSCHILD 1975; II'ICHEV et al. 2003; PASTORI et al. 2008; MONTEIRO et al. 2008a). The placement of a high density of diffusers causes added labor costs for large orchards. New types of pheromone dispersion technology are being studied (JENKINS 2002; STELINSKI et al. 2007) to make the diffusers more affordable and easier to install. Mating disruption for tortricids has several advantages, including pesticide reduction; however, the occurrence of $A$. fraterculus requires the use of insecticides in apple orchards of subtropical region of Brazil (MONTEIRO et al. 2008a).

The objective of this study was to test the efficacy of a mating disruption protocol that uses a low density of diffusers compared with the conventional methods for the control of oriental fruit moths in subtropical conditions.

\section{MATERIALS AND METHODS}

Description of the experiment. The efficiency of mating disruption for control of Oriental fruit moth was evaluated in two commercial apples orchards (Agrícola Fraiburgo Ltda and Fischer Fraiburgo Agrícola) in Fraiburgo, SC, Brazil, in the 2001/02, 2002/03, 2004/05, 2005/06 and 2006/07 growing seasons. These orchards were selected due to high pest infestations in the recent years. Each orchard was randomly subdivided into two blocks, and one block was treated with Biolita ${ }^{\circledR}$, mating disruption formulation (Chem Tica International, San Jose, Costa Rica) and the other block of apple trees managed using no pheromone control (conventional pesticide) separated by $50-70 \mathrm{~m}$. The first orchard was 100 ha and the treatment block was 6.9 ha (mating disruption) and 5.6 ha (conventional pesticide) in the 2001, 2002 and 2004. The second orchard in the last two years was 250 ha and each block was 5.0 ha (mating disruption) and 6.0 ha (conventional pesticide). The blocks had two plots as repetition. Gala was the commercial variety of apples with $4.5 \mathrm{~m}$ of space between tree rows and $1.3 \mathrm{~m}$ between individual plants. The Gala harvest usually begins in late January to late February. Fuji cultivar pollinators, which produce commercialized fruit, comprised $10 \%$ of the apple trees and are harvested from March $10^{\text {th }}$.

Conventional pesticide and pest monitoring. The control of oriental fruit moth in conventional pesticide block was followed by a phytosanitary treatment between September and April. The spraying was applied based on the number of males captured, with 20 moths/trap/day established as the level of control. Monitoring of oriental fruit moth was performed using BioGrafolita ${ }^{\circledR}$ (Biocontrol, São Paulo, Brazil) in Delta traps with pheromones. Traps were changed every 45 days. Three traps were installed at a height of $1.7 \mathrm{~m}$ in each plot (six by blocks). The number of males was counted and removed twice a week between September and April 
of each year, which corresponds to the time at the beginning of apple flowering and after harvest of the Fuji pollination apples. In the 2001-02 growing season, monitoring began in December, due to a market shortage of the pheromone formulation. In each growing seasons studied, some spraying was performed close to harvest due to the presence of fruit flies, which were monitored with two McPhail traps in each plot and BioAnastrepha ${ }^{\circledR}$ attractant (Biocontrol, São Paulo, Brazil). The level of control of fruit flies was 0.5 captures per trap/ day. Conventional phytosanitary management in the Fraiburgo region is performed with clorpyrifos (Lorsban 480 BR), fenitrothion (Sumithion $500 \mathrm{CE}$ ), phosmet (500 Imidan PM) and tebufenozide (Mimic SC 240) to control tortricids moths, and carbaryl (Sevin $850 \mathrm{PM}$ ), malathion (Malathion $500 \mathrm{CE}$ ) and methidathion (Supracid $400 \mathrm{CE}$ ) are used to control fruit flies. Clorpyrifos and tebufenozide were sprayed to control the first generation of pests.

Mating disruption. Both mating disruption and conventional pesticide were treated with insecticide at pre-flowering and petal fall for thinning, due the control of the first generation $G$. molesta adults and to installation of mating disruption formulation. Biolita ${ }^{\circledR}$ consists of a polypropylene diffuser $(9 \times 12 \mathrm{~cm})$ containing $4.10 \mathrm{~g}$ of a $90: 6: 1$ mixture of (Z)-8-dodecenyl acetate (89.93\%); (E)8-dodecenyl acetate (6.01\%); (Z)-8-dodecene-1-ol (1.01\%), as well as inert compounds (3.05\%). The diffuser formulation contains lauryl alcohol, which belongs to the chemical group of aliphatic esters with the following formulas: $\mathrm{C}_{14} \mathrm{H}_{2} \mathrm{O}_{2}, \mathrm{C}_{14} \mathrm{H}_{26} \mathrm{O}_{2}$ and $\mathrm{C}_{12} \mathrm{H}_{24} \mathrm{O}$. Twenty dispensers were installed per hectare, and the installation date varied between years and depended on the phenological stage of fruit development and the estimated date of harvest, which lasts of 20 to 30 days. The installation dates were December $5^{\text {th }} 2001$, November $11^{\text {th }} 2002$, November $29^{\text {th }} 2004$, November $14^{\text {th }} 2005$ and November $20^{\text {th }} 2006$. One diffuser was placed on top of a single plant, and others were distributed every $20 \mathrm{~m}$ around the edge of the orchard and spaced 25 $\mathrm{m}$ inside the orchard. Mating disruption plots were sprayed with clorpyrifos at the time of pheromone diffuser installation, with the objective of reducing adult numbers. The period of estimated efficiency of the mating disruption formulation was 120 days according to the manufacturer's recommendation (www.biocontrole.com.br). The occurrence of pests was monitored under the same conditions held in the plots of conventional treatment.

Evaluation of the effectiveness of mating disruption. The efficiency of the mating disruption formulation in confusing the chemical communication between male and female oriental fruit moths was calculated by the mating interruption index (MII), $\mathrm{MII}=(\mathrm{M}-\mathrm{P} / \mathrm{P}) * 100$, where $\mathrm{M}$ is the average number of males captured per trap in mating disruption plots and $\mathrm{P}$ is the number of captures in the conventional pesticide plots (STELINSKI et al. 2007). The total average number of insects captured per trap in the mating disruption plots, after installation of mating disruption, was compared with that obtained in conventional pesticide plots. The Biolita ${ }^{\circledR}$ field efficiency period was calculated from the reduction in mating interruption index for each sample over time

Damage assessment. The efficiency of the two control programs was compared by estimating the damage of Gala fruit caused by Oriental fruit moth. The damage was defined by the presence of a penetration hole that contained waste and the fruit were cut open for identification of larvae. The evaluation was performed at harvest, by inspection of all of the fruit from 10 selected apple trees in each plot. Damage in Fuji apples were assessed roughly 20 days later, with the aim of verifying any benefit in this variety, after the reduction in efficiency pheromone in Gala apples. The harvest dates of Gala fruit were February $25^{\text {th }} 2002$, February $10^{\text {th }} 2003$, February $17^{\text {th }}$ 2005 , February $20^{\text {th }} 2006$ and February $12^{\text {th }} 2007$, in Fuji apples were March $17^{\text {th }} 2002$, March $2^{\text {nd }} 2003$, March $9^{\text {th }} 2005$ and March $4^{\text {th }} 2007$, not assessed in the 2005-06 growing season.

Data analysis. Data showing the number of Oriental fruit moth males are presented as the cumulative average in three traps by plot. The values were transformed using $\log (x+0.5)$ and analyzed using analysis of variance (ANOVA). Means were compared using Tukey's test with 5\% level of significance (Statgraphics Centurion XV version 1.15.2002, StatPoint ${ }^{\mathbb{R}}$ ). The data from the assessment of fruit damage were transformed by taking $\sqrt{ }(x+0.5)$ to stabilize the variance of the means and were compared using Tukey's test $(P<$ 0.05). (Statgraphics Centurion XV version 1.15.2002, StatPoint $\left.{ }^{\mathbb{R}}\right)$.

\section{RESULTS AND DISCUSSION}

2001-2002. Oriental fruit moth was monitored starting in December, without data on the population size prior to the installation of the mating disruption system. The field efficiency period was 137 days, 17 days longer than estimated, and the mating interruption index for this period was $99.3 \%$ (Table 1). During the field efficiency period, the population in the mating disruption plots was significantly lower 
than in the no pheromone control (conventional pesticide) plots $(\mathrm{d}=1, F=67.51, p<0.001)$, by close to a factor of 134 (Fig. 1).

For the Gala variety, there was no difference in damage from Oriental fruit moth between the two treatments; however, G. molesta damage was around 10 times lower for the Fuji variety in the mating disruption plots (Table 2). During the field efficiency period of mating disruption, there was one insecticide application in mating disruption plots and three sprayings of insecticides in the conventional pesticide plots for Oriental fruit moth (Fig. 2). This year was not necessary to control $A$. fraterculus in mating disruption plots; however, one insecticide was performed in conventional plots.

2002-2003. The field efficiency period was 109 days and the mating interruption index was $95.5 \%$ (Table 1). The efficiency was reduced by $9.5 \%$ between February $26^{\text {th }}, 2003$, and the end of the period of estimated efficiency. The number of captures during the field efficiency period was 6.7 times higher in the conventional pesticide plots than the mating disruption plots $(\mathrm{d}=1, \mathrm{~F}=88.87, \mathrm{p}<$ 0.001) (Fig. 1).

The damage from Oriental fruit moth in the Gala variety was low for both treatments than 2001-2003, but there was more damage in mating disruption plots relative to conventional pesticide plots (Table 2). For the Fuji variety, G. molesta damaged more fruit in the conventional pesticide plots than in the mating disruption plots. There was one insecticide for control of Oriental fruit moth and A. fraterculus in the mating disruption plots (Fig. 2 ), while on the conventional pesticide plots were sprayed five additional times.

2004-2005. The number of Oriental fruit moth males captured was 10.4 times higher in the conventional pesticide plots in relation mating disruption plots $(\mathrm{d}=1, \mathrm{~F}=61.28, \mathrm{p}<0.001)$ (Fig. 1). The field efficiency period lasted 112 days and the mating interruption index remained high (80.8\%), around $2.5 \%$ higher than the mating interruption index in the period of estimated efficiency (Table 1).

The fruit of the Gala variety had $30 \%$ less damage from Oriental fruit moth in the mating disruption plots than in the conventional pesticide plots (Table 2). Oriental fruit moth caused heavy losses of the Fuji variety in both treatments, but there was almost $79.4 \%$ more damage in the conventional pesticide plots than in the mating disruption plots. Six more insecticide applications were performed on the efficiency period in the conventional pesticide plots than in the mating disruption plots. Only one treatment was carried out for fruit flies in the mating disruption plot (Fig. 2).

2005-2006. The mating disruption formulation remained efficient through the harvest of the Gala variety, totaling 119 days of action. During the field efficiency period, the mating interruption index was $77.2 \%$. The number of oriental fruit moth captured in the conventional pesticide plots was 7.2 times higher than in the mating disruption plots $(\mathrm{d}=1, \mathrm{~F}=54.29$, $\mathrm{p}<0.001$ ) (Fig. 1).

The damage caused by Oriental fruit moth on the Gala variety was significant (Table 2). There were six additional sprays applied in the conventional pesticide plots, while four additional insecticide treatments were for A. fraterculus (Fig. 2). In comparison, only one treatment was applied to the Oriental fruit moth in the mating disruption plots and two for $A$. fraterculus.

2006-2007. The field efficiency period lasted 91 days, and the mating interruption index was the lowest of the five years $(71.4 \%)$ (Table 1$)$. The mating interruption index was reduced by $14.6 \%$ up to 120 days from the period of estimated efficiency. The capture of Oriental fruit moth was higher in the conventional pesticide plots than in the mating disruption plots ( $\mathrm{d}=1, \mathrm{~F}=10.11, \mathrm{p}=0.0022)$ (Fig. 1).

Damage to Gala fruit did not differ between the two pests or between the two treatments. $G$. molesta caused similar damage to the Fuji variety with both treatments. The difference of six sprays between the two treatments on the field efficiency period (Fig. 2).

General mating disruption. The total capture (September-April) of Oriental fruit moth in the mating disruption plots was lower than in the conventional pesticide plots over five years $(\mathrm{d}=1$, $\mathrm{F}=134.32, \mathrm{p}<0.001$ ) (Fig. 3), with averages of 7.9 and 25.7 males per sampling day, respectively. There were significantly fewer males captured in both the mating disruption and the conventional pesticide plots in crop years 2001-02, 2002-03 and 2004-05 (from September to April) than in 2005-2006 and 2006-2007 ( $d=4, F=13.15, p<0.001)$. The crop years 2001-2005 and 2005-2007 had averages ranging from 2.9 to 12.6 and from 14.0 to 40.7 males per sample, respectively. The Oriental fruit moth population did not differ between plots before installation of mating disruption (before November), averaging 31.1 in the mating disruption and 57.3 in the conventional pesticide plots. Fig. 1 shows the cumulative capture of Oriental fruit moth males from September $4^{\text {th }}$ to April $23^{\text {rd }}$ of each year.

The average number of males during the period of estimated efficiency (November-March) was 7.6 times higher in conventional pesticide plots 
$(\mathrm{d}=1, \mathrm{~F}=173.99, \mathrm{p}<0.001)$ over five years, averaging 2.3 males in the mating disruption plots and 17.5 in the conventional pesticide plots (Fig. 1). There were more males in the first three years than in the last two years for both mating disruption $(\mathrm{d}=4, \mathrm{~F}=49.37$, $\mathrm{p}<0.001)$ and conventional pesticide plots $(\mathrm{d}=4, \mathrm{~F}=$ $8.28, \mathrm{p}<0.001$ ), with averages ranging from 0.6 to 11.0 and 4.8 to 27.3 males per sample, respectively. The mating interruption index during the period of estimated efficiency was $80.7 \%$, on average over five years, with significant differences between the years $(d=4, F=5.69, p=0.0003)($ Table 1).

The average field efficiency period of Biolita ${ }^{\circledR}$ over five years was 113 days. The average mating interruption index over five years on the field efficiency period (FEP) was $84.8 \%$ (Table 1). During the FEP, the first two years had the highest mating interruption index relative to the other years $(d=4$, $\mathrm{F}=9.15, \mathrm{p}<0.001$ ), with averages of 99.3 and $95.5 \%$ for the early and later years, respectively. Beginning in February of each year, the mating interruption index decreased in the mating disruption concurrently with the reduction in the pheromone concentration. Meanwhile, the capture of Oriental fruit moth during the Fuji ripening and harvesting period (March and April) was significantly lower in the MATING DISRUPTION plots (average of 5.71 males) than in the conventional pesticide plots (average of 13.91) $(d=1, F=28.23, p<0.001)$.

The number of insecticide applications during the field efficiency period was $28 \%$ lower in the mating disruption plots than in the conventional pesticide plots (Fig. 2). On average, there was one insecticide spray for G. molesta in the mating disruption in each year during the field efficiency period, except for 2004-05, and fruit flies was performed only 1.2 sprays. The number of insecticides for both pests was higher in the second and third years (2002 and 2004), in the conventional pesticide plots than in mating disruption plots, while in the second orchard (20052007) there was an increase of one insecticide over the fruit flies. The average number of insecticides in conventional pesticide plots in five years was 4.2 and 3.0, respectively, for Oriental fruit moth and $A$. fraterculus.

The average damage of Oriental fruit moth to the Gala variety was lower in the mating disruption plots than in the conventional pesticide plots $(\mathrm{d}=1$, $\mathrm{F}=11.25, \mathrm{p}=0.0009$ ) over five years, with averages of $0.20 \pm 0.05 \%$ and $0.53 \pm 0.06 \%$, respectively. Oriental fruit moth caused major damage in the crop years 2001-2002, 2004-2005 and 2006-2007 $(d=4, F=10.90, p<0.001)$ (Table 2). There were no differences between the mating disruption and conventional pesticide plots in the level of damage caused by G. molesta over five years for the Fuji variety, with averages of $7.17 \pm 2.01 \%$ and 12.90 $\pm 2.01 \%$, respectively. In 2004-2005, an average of $35.56 \%$ of fruit had damage caused by Oriental fruit moth on both treatments plots, which was roughly 20.8 times higher than the averages for other years $(d=3, F=55.90, p<0.001)$, despite insecticide spraying.

The risk of economic loss to fruit in commercial orchards did not allow the inclusion of a control plot without insecticides, especially with the occurrence of fruit flies, A. fraterculus in orchards in Southern Brazil. The damage caused by fruit flies in southern Brazil ranges between 18.5 and $98.0 \%$ of apples (TEIXEIRA et al. 2011). In such conditions, the presence of fruit flies (Tephritidae) justifies the use of insecticides in orchards with mating disruption. Insecticides registered for fruit flies belong to organophosphorus chemicals, all broad spectrum, which can have an effect on Oriental fruit moth (MILLER et al. 2006).

The success of the mating disruption technique depends on the bio-ecology of pests. Oriental fruit moth larvae develop in burrknots, these increases in size and number over the life of the tree, resulting in increasingly pest (BISOGNIN et al. 2012). In Brazil, G. molesta does not undergo an obligatory diapause (HICKEL et al. 2003), and generations overlap in the spring. Thus, chemical control cannot be limited to the first generation of Oriental fruit moth, as recommended elsewhere (TRIMBLE et al. 2001, 2004). After the control in early spring, spraying is necessary when installing the mating disruption system. Therefore, the combination of mating disruption with insecticide is necessary from November to January, in order to reduce early-developing populations as well as the risk of fruit damage by late generations and/or populations that migrate from nearby peach orchards, as noted by II'ichev et al. (2003). These issues are most evident in situations with a low-density of diffusers (STELINSKI et al. 2007).

The control strategy for Oriental fruit moth using a mating disruption protocol with 20 diffusers per ha was better than conventional management with insecticides alone. In Subtropical conditions was possible to prove the effectiveness of pheromone treatment for the capture of Oriental fruit moth males. Capture was 7.6 times lower in the mating disruption plots than in the conventional pesticide plots during the period of estimated efficiency. Similar results were obtained by Kovanci et al. (2005) using Isomate 250 M-100 diffusers, and by Stelinski et al. (2007) 
with Puffer ${ }^{\circledR}$ aerosol dispensers (2.5 dispensers/ha).

The efficiency of mating disruption in the Gala variety during the field efficiency period was high $(81.4-99.3 \%)$ for the first three years. These results are contrary to the trend observed by Suckling et al. (2007), who showed that mating disruption does not exceed $90 \%$ using diffusers at low density. The reduction of the mating interruption index in the last two years may be related to the Oriental fruit moth population increase of almost 25 fold during those years. High pest populations can compromise the efficiency of a protocol for gender confusion, as mentioned by Stelinski et al. (2007). In addition, pheromone dispensers can be more easily influenced by wind when using a low rather than high (500 dispensers) density of diffusers. The greater pheromone amount released by the Biolita ${ }^{\circledR}$ diffusers compensates for the lowdensity distribution of the diffusers in the orchards. The deposition of pheromones in plants and soil is likely to be influenced by the effects of rain, as with microencapsulated formulations (JENKINS 2002).

In the present study, the average damage caused by Oriental fruit moth was low for the Gala variety, and the low levels of damage were similar between treatments. According to Miller et al. (2006), there was a trend of increased fruit damage when the low density diffusers were used. The reduced use of insecticides on Gala variety in the mating disruption plots can provide additional benefits to the agroecosystem (MONTEIRO et al. 2004a, b; MONTEIRO et al. 2008b).

The four-month interruption of Oriental fruit moth mating was not sufficient to reduce the pests in the Fuji cultivar pollinators, and an increase in damage was observed. This may be related to the natural reduction in the release of pheromones and the efficiency of mating disruption, coupled with the reduction in the number of insecticide sprayings. For the Fuji variety, it is necessary to continue the insecticide control strategy to prevent high levels of damage, such as those recorded in 2004-2005.

TABLE 1- Period of effectiveness of mating disruption for control of Grapholita molesta and mating interruption index in apple orchards for five years, under Subtropical climate, Fraiburgo (SC), Brazil.

\begin{tabular}{lcccccc}
\hline \multirow{2}{*}{ Year } & \multicolumn{3}{c}{ M.D. efficiency ${ }^{1}$} & & \multicolumn{2}{c}{ MDI $^{4}$} \\
\cline { 2 - 4 } \cline { 6 - 7 } & PEE $^{2}$ & FEP $^{3}$ & Day & & PEE & FEP \\
\hline $2001-02$ & $4 / 4 / 02$ & $21 / 4 / 02$ & 137 & & $99,2 \mathrm{c}$ & $99,2 \mathrm{~b}$ \\
$2002-03$ & $9 / 3 / 03$ & $26 / 2 / 03$ & 109 & & $87,3 \mathrm{bc}$ & $95,5 \mathrm{~b}$ \\
$2004-05$ & $29 / 3 / 05$ & $21 / 3 / 05$ & 112 & & $78,8 \mathrm{~b}$ & $80,8 \mathrm{a}$ \\
$2005-06$ & $14 / 3 / 06$ & $13 / 3 / 06$ & 119 & & $77,2 \mathrm{~b}$ & $77,2 \mathrm{a}$ \\
$2006-07$ & $20 / 3 / 07$ & $19 / 2 / 07$ & 91 & & $61,0 \mathrm{a}$ & $71,4 \mathrm{a}$ \\
\hline${ }^{1}$ Mating distuption (Biolita 8), Biocontrole, São Paulo) & & \\
2 Period efficiency estimated by the manufacturer, ${ }^{3}$ Field efficiency period \\
${ }^{4}$ Mating distuption index
\end{tabular}

TABLE 2- Damage of Grapholita molesta in Gala and Fuji apple with mating disruption and conventional pesticide blocks for five years, Fraiburgo (SC), Brazil.

\begin{tabular}{llcccccc}
\hline Year & \multicolumn{1}{c}{ Treatment } & n fruit & \multirow{2}{*}{ n plant } & Gala & n fruit & n plant & Fuji \\
\hline $2001-02$ & Mating disruption & 1070 & 12 & $0,28 \pm 0,76 \mathrm{a}$ & 1274 & 12 & $0,42 \pm 0,17 \mathrm{a}$ \\
& Conventional pesticide & 1160 & 12 & $1,46 \pm 0,76 \mathrm{a}$ & 622 & 12 & $4,31 \pm 1,21 \mathrm{~b}$ \\
$2002-03$ & Mating disruption & 6706 & 40 & $0,12 \pm 0,04 \mathrm{~b}$ & 5037 & 32 & $0,39 \pm 0,09 \mathrm{a}$ \\
& Conventional pesticide & 5376 & 40 & $0,02 \pm 0,03 \mathrm{a}$ & 5066 & 32 & $1,53 \pm 0,34 \mathrm{~b}$ \\
$2004-05$ & Mating disruption & 9403 & 40 & $0,31 \pm 0,14 \mathrm{a}$ & 4328 & 18 & $26,89 \pm 3,17 \mathrm{a}$ \\
& Conventional pesticide & 6102 & 40 & $1,00 \pm 0,14 \mathrm{~b}$ & 4620 & 18 & $48,24 \pm 5,17 \mathrm{~b}$ \\
$2005-06$ & Mating disruption & 4029 & 20 & $0,07 \pm 0,03 \mathrm{a}$ & - & - & - \\
& Conventional pesticide & 4170 & 20 & $0,42 \pm 0,06 \mathrm{~b}$ & - & - & - \\
$2006-07$ & Mating disruption & 2686 & 20 & $0,61 \pm 0,19 \mathrm{a}$ & 7394 & 20 & $2,19 \pm 0,17 \mathrm{a}$ \\
& Conventional pesticide & 6731 & 20 & $0,48 \pm 0,21 \mathrm{a}$ & 3234 & 20 & $1,99 \pm 0,52 \mathrm{a}$ \\
\hline
\end{tabular}

Means within a column followed by the same letter are not significantly different $(P<0.05$. 

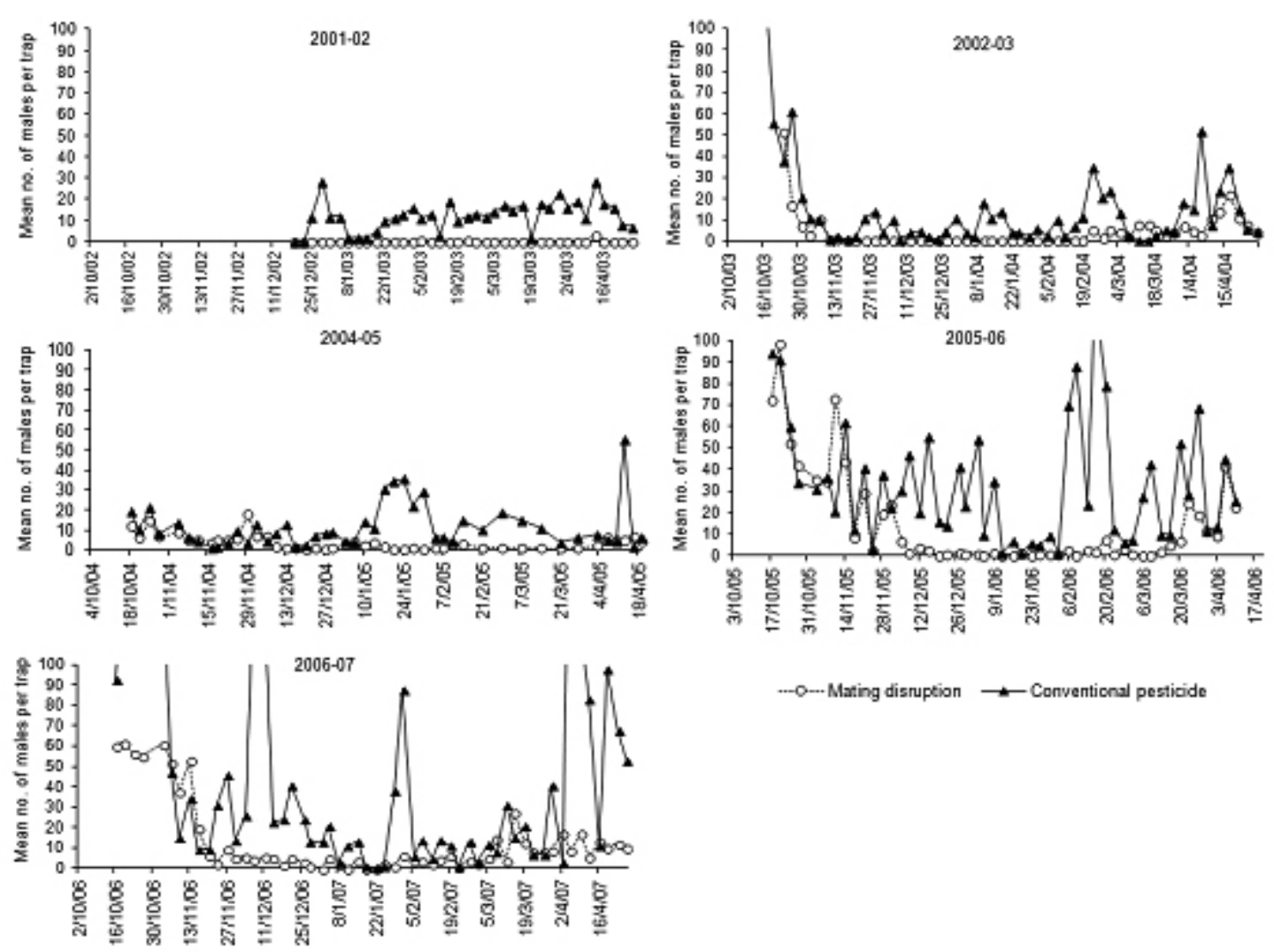

-..-Mating disnption $\rightarrow$ Conventional pesticide

FIGURE 1 - Mean of Grapholita molesta male in pheromone traps in apple orchards, with mating disruption and conventional pesticide blocks for five years under Subtropical climate, Fraiburgo (SC), Brazil.

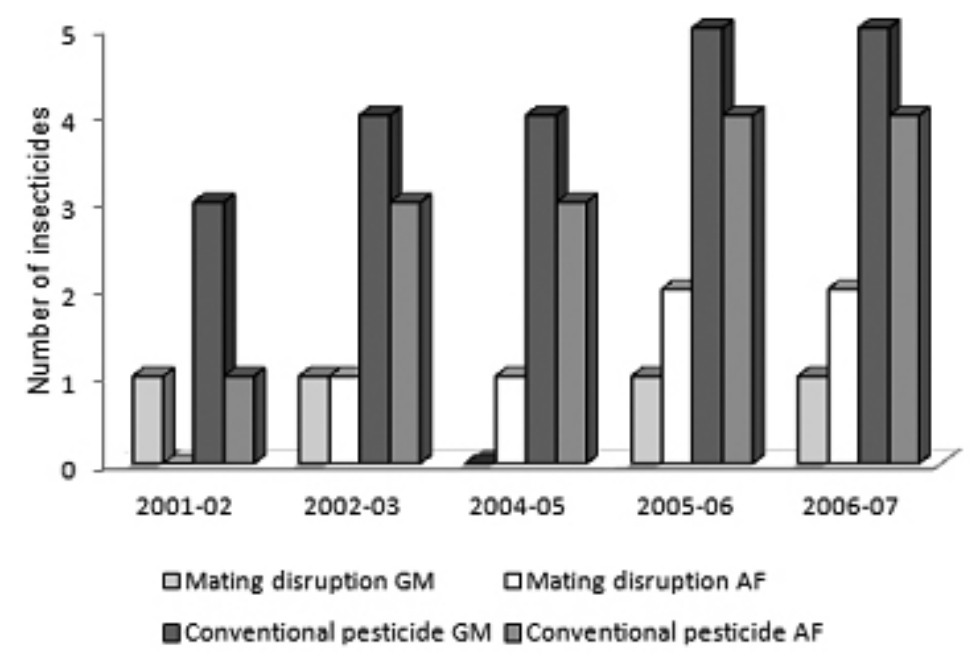

FIGURE 2 - Number of insecticides in mating disruption and conventional pesticide plots for the control of Grapholita molesta (GM) and Anastrepha fraterculus (AF) in the orchard of apple trees for five years, under Subtropical climate, Fraiburgo (SC), Brazil. 


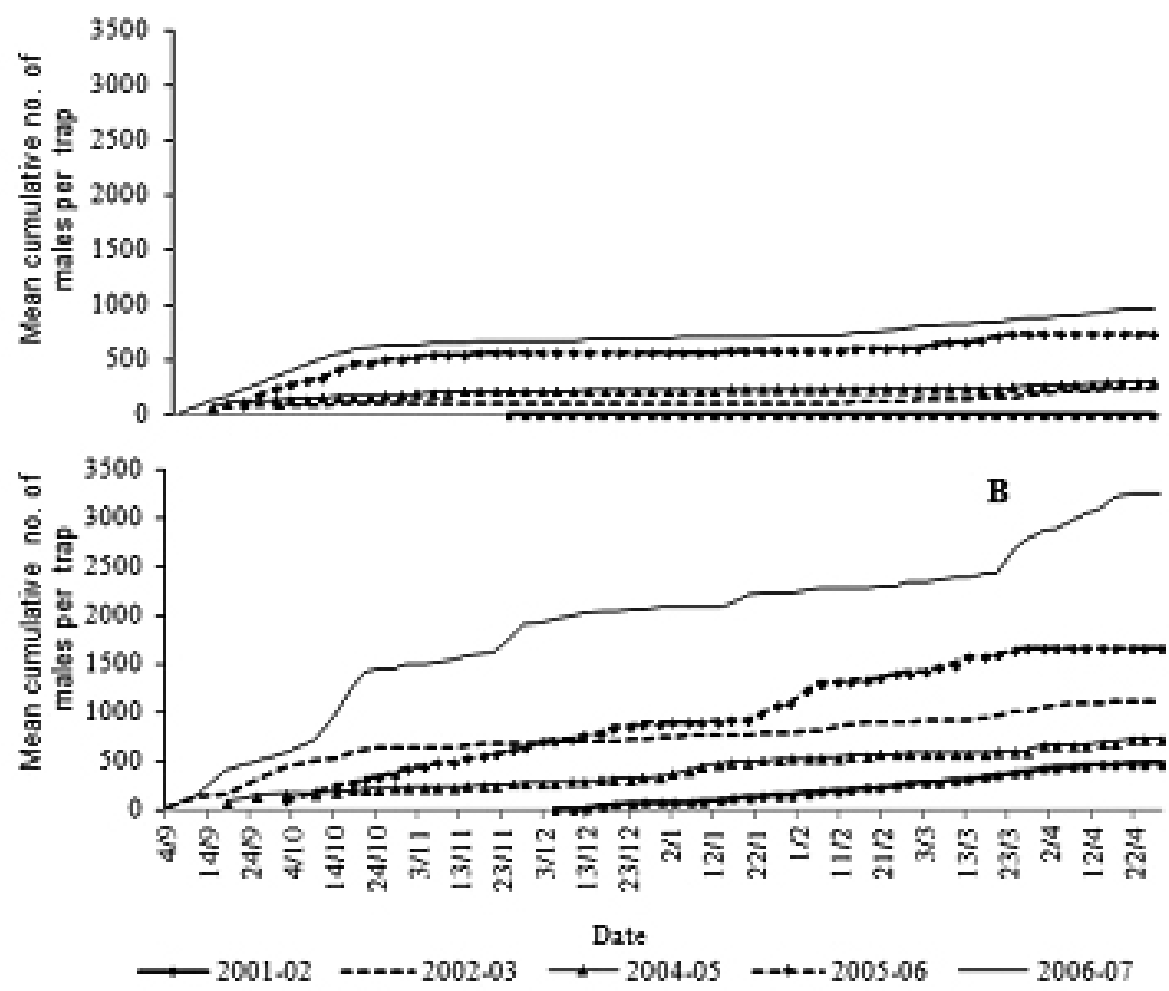

FIGURE 3 - Mean cumulative of Grapholita molesta male in pheromone traps in apple orchards, with mating disruption (A) and conventional pesticide (B) blocks for five years, under Subtropical climate, Fraiburgo (SC), Brazil.

\section{ACKNOWLEDGEMENTS}

The authors express their thanks to the agricultural companies Fischer Fraiburgo Agrícola Ltda. and Agrícola Fraiburgo for the use of experimental orchards and for aiding in the implementation of the study.

\section{REFERENCES}

BISOGNIN, M.; ZANARDI, Z.O.; NAVA, D.E.; ARIOLI, J.C.; BOTTON, M.; GARCIA, S.M.; CABEZAS F.M. Burrknots as food source for larval development of Grapholita molesta (Lepidoptera: Tortricidae) on apple trees. Environmental Entomology, State College, v. 41, p. 849-854, 2012.

CARDE,'R.T.; MINKS, A.K. Control of moths by mating disruption: successes and constraints. Annual Reviews Entomology, Palo Alto, v. 40, p. 559-585, 1995. HICKEL,E.R.; HICKEL, G.R.; SOUZA, O.F.F.; VILELA, E.F.; MIRAMONTES, O. Population dynamics of oriental fruit moth in peach and plum orchards. Pesquisa Agropecuária brasileira, Brasília, v. 38, p. 325-337, 2003 a.
HICKEL, E.R.; VILELA, E.F.; SOUZA, O.F.F.; MIRAMONTES, O. Forecasting flight activity of Grapholita molesta (busk) in peach and plum orchards based on pheromone trap catches and degree-day accumulation. Revista Ciências AgroVeter, Lages, v. 2, p. 30-41, 2003 b.

IL'ICHEV, L.; WILLIAMS, D.G.; DRAGO, A Distribution of the oriental fruit moth Grapholita molesta Busck (Lep., Tortricidae) infestation on newly planted peaches before and during 2 years of mating disruption. Journal Applied Entomology, Goettingen, v. 127, p. 348-353, 2003.

JENKINS, J.W. Use of mating disruption in cotton in North and South America. IOBC/WPRS Bull, Mörlenbach, v. 25, p. 21-26, 2002.

KANGA, L.H.B.; PREE, D.J.; PLAPP, F.W.; VAN LIER, J.L. Sex-linked altered acetylcholinesterase resistance to carbamate insecticides in adults of the oriental fruit moth, Grapholita molesta (Lepidoptera: Tortricidae). Pesticide Biochemistry Physiology, Amherst, v. 71, p. 29-39, 2001. 
KOVALESKI, A.; SUGAYAMA, R. L.; MALAVASI, A. Movement of Anastrepha fraterculus from native breeding sites into apple orchards in southern Brazil. Entomologia Experimentalis et Applicata, Dordrecht, v. 91, p.457-463, 1999.

KOVANCI, O.B.; SCHAL, C.; WALGENBACH, J.F.; KENNEDY, G.G. Comparison of Mating Disruption with Pesticides for Management of Oriental Fruit Moth (Lepidoptera: Tortricidae) in North Carolina Apple Orchards. Journal Economic Entomology, Lanham, v. 98 , p. 1.248-1.258, 2005.

LORENZATO, D. Lepidópteros nocivos em fruteiras rosáceas no Sul do Brasil. Ipagro, Porto Alegre, v. 31, p. 7-10, 1988.

MILLER, J. R.; GUT, L.J.; DE LAME, F.M.; STELINSKI, L.L. Differentiation of competitive vs. non-competitive mechanisms mediating disruption of moth sexual communication by point sources of sex pheromone: (Part 2) case studies. Journal Chemical Ecology, New York, v. 32, p. 2.115-2.143, 2006.

MONTEIRO, L.B.; DOLL, A.; BOEING, L.F. Effect of Neoseiulus californicus McGregor (Acari: Phytoseiidae) density of on the control of red mite in apple trees. Revista de Brasileira de Fruticultura, Jaboticabal, v. 30, p. 902-906, 2008 b.

MONTEIRO, L.B.; SOUZA, A.; BELLI, E.L. Mating disruption for the control of Grapholita molesta (Lepidoptera: Tortricidae), in Fraiburgo, Santa Catarina, Brazil. Bragantia, Campinas, v. 67, p. 191-196, 2008a.

MONTEIRO, L.B.; SOUZA, A.; BELLI, E.L. Parasitim on Eriosoma lanigerum (Homóptera: Aphididae) by Aphelinus mali (Hymenoptera: Encyrtidae) on apple orchards, in Fraiburgo country, State of Santa Catarina, Brazil. Revista Brasileira de Fruticultura, Jaboticabal, v. 26, p. 550-551, 2004a.

MONTEIRO, L.B.; SOUZA, A.; BELLI E, L.; SILVA, R.B.Q.; ZUCCHI, R.A. Occurrence of Trichogramma pretiosum riley (Hymenoptera: Trichogrammatidae) on eggs of Bonagota cranaodes (meyrick) (Lepidoptera: Tortricidae) in apple tree. Revista de Brasileira Fruticultura, Jaboticabal, v. 26, p. 171-172, 2004b.

PASTORI, P.L.; ARIOLI, C.J.; BOTTON, M.; MONTEIRO, L.B.; MAFRA NETO, A. Evaluation of the sexual disruption technique using Splat ${ }^{\circledR}$ dispensers to control Bonagota salubricola (Meyrick) and Grapholita molesta (Busck) (Lepidoptera:
Tortricidae) in the pre-harvest of Fuji apple cultivar. BioAssay, Piracicaba, v. 3, p. 1-8, 2008.

PITCAIRN, M.J.; ZALOM, F.G.; RICE, R.E. Degree-day forecasting of generation time of Cydia pomonella (Lepidoptera: Tortricidae) populations in California. Environmental Entomology, State College, v. 21, p. 441-446, 1992.

RICE, R.E.; WEAKLEY, C.V.; JONES, R.A. Using degree-days to determine optimum spray timing for the oriental fruit moth (Lepidoptera:Tortricidae). Journal Economic Entomology, Lanham, v. 77, p. 698-700, 1984.

RIEDL, H.; CROFT, B.A.; HOWITT, A.J. Forecasting codling moth phenology based on pheromone trap catches and physiological-time models. Canadian Entomologist, Quebec, v. 108, p. 449-460, 1976.

ROTHSCHILD, G. H. L. Control of oriental fruit moth (Cydia molesta (Busck) (Lepidoptera, Tortricidae) with synthetic female pheromone. Bulletin of Entomological Research, Cambridge, v. 65 , p. $473-490,1975$.

SIEGWART, M.; MONTEIRO, L.B.; MAUGIN, S.; OLIVARES, J.; CARVALHO, S.M.J.; SAUPHANOR, B. Tools for resistance monitoring in oriental fruit moth (Lepidoptera: Tortricidae) and first assessment in Brazilian populations. Journal Economic Entomology, Lanham, v. 104, p. 636645, 2011.

STELINSKI, L. L.; GUT, L.J.; HAAS, M.; MCGHEE, P.; EPSTEIN, D. Evaluation of aerosol devices for simultaneous disruption of sex pheromone communication in Cydia pomonella and Grapholita molesta (Lepidoptera: Tortricidae). Journal Pest Science, Heidelberg, v. 80, p. 225-233, 2007.

STRAND, L.L. (ed.). Integrated pest management for stone fruits. Oakland: University of California, 1999. p. 264.

SUCKLING, D.M.; DALY, J.M.; CHEN, X.; KARG, G. Field electroantennogram and trap assessments of aerosol pheromone dispensers for disrupting mating in Epiphyas postvittana. Pest Management Science, Oxford, v. 63, p. 202-209, 2007. 
TEIXEIRA, R.; CASSANDRO, V.T.A.; BOFF, M.I.C.; RIBEIRO, L.G. Controle de pragas e doenças, maturação e qualidade de maçãs 'imperial gala' submetidas ao ensacamento. Revista Brasileira de Fruticultura, Jaboticabal, v. 33, p. 394-401, 2011.

TRIMBLE, R.M.; PREE, D.J.; BARSZCZ, E.S.; CARTER, N.J. Comparison of a sprayable pheromone formulation and two hand-applied pheromone dispensers for use in the integrated control of Oriental fruit moth (Lepidoptera: Tortricidae). Journal Economic Entomology, Lanham, v. 97, p. 482-489, 2004.
TRIMBLE, R.M.; PREE, D.J.; CARTER, N.J. Integrated control of oriental fruit moth (Lepidoptera: Tortricidae) in peach orchards using insecticide and mating disruption. Journal Economic Entomology, Lanham, v. 94, p. 476-485, 2001. 